\title{
Molecular detection of adulteration in commercial buffalo meat products by multiplex PCR assay
}

\author{
Lanping WANG ${ }^{1}$, Xinru $\mathrm{HANG}^{2}$, Rongqing GENG ${ }^{2 *}$
}

\begin{abstract}
Authentication of commercial buffalo meat products has become a market concern. This study intended to develop and validate a highly species-specific multiplex PCR assay for authentication of buffalo meat products. Four pairs of species-specific primers were used to target mitochondrial cytochrome oxidase I (COI) gene. The assay generated the expected PCR products of 313, 255, 294 and 177 bp for buffalo meat, cattle meat, pork meat and duck meat, respectively. The multiplex PCR assay was sensitive enough to detect $1 \mathrm{pg}$ pure DNA and $0.1 \%(\mathrm{w} / \mathrm{w})$ adulterated meat under mixed matrices. Market survey revealed about $35.3 \%$ of buffalo meat products are adulterated with cattle meat, pork meat or duck meat in China. The adulteration was found in all food product types including minced meat, frozen rolls, boiled meat, meat ball, vacuum-packed meat and jerky. These findings showed that multiplex PCR assay are potentially reliable techniques for detection of adulteration in raw and processed buffalo meat products.
\end{abstract}

Keywords: buffalo meat; commercial fraud; adulteration; multiplex PCR; cytochrome oxidase I gene.

Practical Application: Develop a multiplex PCR assay for the detection of adulteration in commercial buffalo meat products.

\section{Introduction}

Existing research on product fraud and counterfeiting have defined seven distinct types of food fraud (Spink \& Moyer, 2011). These fraudulent incidents include adulteration, tampering, over-run, theft, diversion, simulation, and counterfeiting. Food authenticity assessment is one of the most crucial issues in the food industry especially for meat and meat products. The non-authenticity of meat and meat products can take different forms (Hargin, 1996; Nakyinsige et al., 2012), but mainly by whole or partial substitution of components with other undeclared alternative meats which are usually cheaper. The consumption of certain meat and meat products is proscribed due to religious reasons in halal meat markets of the world. For Muslim consumers, the major authenticity concerns in meat and meat products include pork substitution, undeclared blood plasma, use of prohibited ingredients, pork intestine casings and non-halal methods of slaughter. Therefore, precise identification of meat species has become a vital element in meat quality control procedures to monitor commercial products.

A number of methods have been developed for species identification to detect and prevent meat substitution on the commercial market including anatomical, histological, microscopical, spectroscopic, chemical, immunological and genetic approaches (Ballin, 2010; Sentandreu \& Sentandreu, 2014; Kumar et al., 2015). In contrast, DNA detection methods have numerous advantages including a higher information content, greater resistance to degradation, increased specificity and sensitivity, and presence in all cell types. Among the developed methods, species-specific PCR assay is considered as a robust one in comparison with other DNA-based methods, and has been widely applied in meat species identification. Both genomic and mitochondrial genes have been targeted for species detection. The mitochondrial encoded gene for mitochondrial cytochrome oxidase I (COI) was selected as the target sequence for species identification because that it is relatively conserved within species and exhibits divergence between species, enabling samples to be identified at the species level in most cases (Quinto et al., 2016).

Buffalo meat has several virtues such as high protein, low fat and cholesterol contents as well as less calories than beef (Murthy \& Devadason, 2003). It is considered as a healthy product for its good nutritional characteristics. Based on several key cardiovascular risk features assessments, consumption of buffalo meat appears associated with several beneficial effects on cardiovascular risk profile, including lower carotid atherosclerotic burden and susceptibility to oxidative stress (Giordano et al., 2010). For these reasons, buffalo meat and meat products are promising and increasing on the international food markets (for example, in many regions including Asia, Southern Europe, South America, and Northern Africa) according to the Food and Agricultural Organization (2017).

In terms of buffalo population and production, China is an important place with the third largest population in the world. Buffalo meat has become more and more popular and has tremendous economic importance due to increasing demands in recent years, especially in central and southern China. The price 
of buffalo meat is significantly higher than beef, mutton and other domestic animal meats.

The aim of this study was to establish a multiplex PCR for simultaneous identification of different meat ingredients using mitochondrial COI gene. The experiment was designed to establish a highly species-specific PCR for identification of buffalo meat adulteration in raw, heat treated and commercial meat samples. Hence, a multiplex PCR assay for accurate and precise detection of the buffalo meat adulteration was developed and validated. The goals were to determine the current situations of meat substitution in buffalo meat and meat products, whether added unwittingly or deliberately, and to provide an efficient way for law enforcement agencies to monitor adulteration.

\section{Materials and methods}

\subsection{Sample collection}

Authentic meat samples were collected including buffalo (Bubalus bubalis), cattle (Bos taurus and Bos indicus), pig (Sus scrofa domesticus) and duck (Anas platyrhynchos). Approximately $50 \mathrm{~g}$ each of authentic meat samples were collected from local abattoirs. The samples were transported to the laboratory under chilled conditions $\left(4^{\circ} \mathrm{C}\right)$ and were then stored at $-20^{\circ} \mathrm{C}$ until further use. These meat samples from different species were identified by PCR amplication method using four pairs of primers of mitochondrial COI gene (Dai et al., 2015; Spychaj et al., 2016), and then confirmed by direct sequencing.

One hundred and eighty-two food samples, including minced meat $(n=32)$, frozen rolls $(n=37)$, boiled meat $(n=34)$, meat ball $(n=30)$, vacuum-packed meat $(n=26)$ and jerky $(n=23)$ were collected from retailers and markets in different provinces of China. These foods represented six mainly types of raw and processed buffalo meat products on the local markets. All samples were cut into small pieces using a sterile scalpel, kept in a sterile plastic bag, and stored at $-20^{\circ} \mathrm{C}$ to prevent DNA degradation.

\subsection{DNA separation and detection}

The extraction of DNA was performed according to the manufacturer's instruction provided using the Tissue Genome DNA purification kit (Promega, Madison, USA). The extraction protocol was used to extract DNA using both raw and processed meat samples. Procedures for DNA extraction were similar, except that processed meat products were washed ahead of extraction. DNA qualities were checked on $1 \%$ agarose gel and DNA concentrations were determined fluorometrically using a Nano-Drop 2000 spectrophotometer (Nano Drop Technologies, Wilmington, USA).

\subsection{PCR primers and amplification}

Different primer pairs used for PCR amplification were presented in Table 1. Species-specific primers were designed from mitochondrial COI gene. These primers were described and published by previous reports (Dai et al., 2015; Spychaj et al., 2016). The primers were synthesized by Nanjing GenScript Biotechnology Co., Ltd (Nanjing, China).
Table 1. Primers for PCR amplification.

\begin{tabular}{ccc}
\hline Species & Primer sequence & $\begin{array}{c}\text { Target } \\
\text { fragment }\end{array}$ \\
\hline Bubalus bubalis & 5'-CTGTGTTCGCCATTATAGGA-3' & 313 bp \\
& 5'-GTGGTTAGATCTACGGTTGAG-3' & \\
Bos taurus & 5'-GAACTCTGCTCGGAGACGAC-3' & $255 \mathrm{bp}$ \\
& 5'-GGTACACGGTTCAGCCTGTT-3' & \\
Sus scrofa & 5'-GGAGCAGTGTTCGCCATTAT-3' & \multirow{2}{*}{$294 \mathrm{bp}$} \\
& 5'-TTCTCGTTTTGATGCGAATG-3' & \\
Anas platyrhynchos & 5'-TAATTGGCACAGCACTCAGC-3' & \multirow{2}{*}{$177 \mathrm{bp}$} \\
& 5'-TTATCAGGGGGACCAATCAG-3' & \\
\hline
\end{tabular}

Optimization of PCR conditions was conducted for the annealing temperature, template concentrations and primer concentrations. The final conditions for simplex and multiplex PCR were performed in a total volume of $25 \mu \mathrm{L}$. Each reaction mixture contained $100 \mathrm{ng}$ of template DNA, $1 \times$ PCR buffer, $2 \mathrm{mM} \mathrm{MgCl}, 200 \mu \mathrm{M}$ of each dNTP, $8 \mathrm{pmol}$ of each primer, 1 unit of Premix Taq DNA polymerase (Takara, China) and sterilized distilled water.

PCR was performed in a Thermal Cycler C1000 (Bio-Rad, Hercules, USA). The amplification conditions included initial denaturation at $95^{\circ} \mathrm{C}$ for $3 \mathrm{~min}$, followed by 35 cycles at $95^{\circ} \mathrm{C}$ for $30 \mathrm{~s}, 60{ }^{\circ} \mathrm{C}$ for $45 \mathrm{~s}, 72{ }^{\circ} \mathrm{C}$ for $45 \mathrm{~s}$. The final extension was performed at $72{ }^{\circ} \mathrm{C}$ for $5 \mathrm{~min}$ and the reactions were stored at $4^{\circ} \mathrm{C}$ until further analysis. A negative control was included with all sets of reactions to monitor for contamination.

$2 \mu \mathrm{L}$ PCR products were mixed with $2 \mu \mathrm{L}$ gel loading solution, and loaded in a $2 \%$ agarose gel. Electrophoretic separation was performed at $80 \mathrm{~V}$ for $40 \mathrm{~min}$. The gels were visualized and photographed in a GelDoc 2000 gel documentation system (Bio-Rad, Hercules, USA). The relative molecular weight of the amplicons was estimated by a DL2000 DNA marker (fragments range from $2000 \mathrm{bp}, 1000 \mathrm{bp}, 750 \mathrm{bp}, 500 \mathrm{bp}, 250 \mathrm{bp}$ to $100 \mathrm{bp}$, vertically).

\subsection{Multiplex PCR assay validation}

The simplex and multiplex assay developed previously was validated for its specificity, reproducibility, sensitivity, and robustness (detection of commercial meat products). For the specificity test, the cross-amplification was tested with different meat species. For the reproducibility test, all meat samples from each species were tested with the assay. For the sensitivity test, two methods were used for assessing the developed assay. Firstly, 10 -fold serial diluted DNA templates $(1000,100,10,1$ and $0.1 \mathrm{pg})$ were prepared and amplified to determine the minimum amount of detection. Secondly, the mimic counterfeiting test was assessed by mixing target meat with different proportions into buffalo meat. The adulteration meat mixtures contained 100\%, 90\%, $75 \%, 50 \%, 25 \%, 10 \%, 5 \%, 1 \%, 0.1 \%$ and $0 \%(\mathrm{w} / \mathrm{w})$ of target meat. For robustness and real-world performance testing, the developed assay was used to test 182 commercial meat products. 


\section{Results and discussion}

\subsection{Specificity and reproducibility test}

The simplex amplifications of all four species-specific primers were first performed using voucher meat samples. The result showed that direct PCR was successful in identifying meat species from raw meat samples (Figure 1). Each species-specific primer pair produced PCR products only from its target species and generated the expected PCR products of 313, 255, 294 and 177 bp for buffalo (Bubalus bubalis), cattle (Bos taurus and Bos indicus), pig (Sus scrofa domesticus) and duck (Anas platyrhynchos), respectively. No PCR product was observed from the negative controls. The multiplex assay for simultaneous detection of the four meat species were successfully developed (Figure 2). Four different PCR fragments corresponding to the expected sizes of the target meat species were detected. No PCR fragment was observed from the negative control. These results showed the applicability of the primers proposed by previous reports (Dai et al., 2015; Spychaj et al., 2016). According to simplex and multiplex PCR results, the four sets of primers had no cross-reactions and unexpected products in any combination, which indicated that the mitochondrial COI gene had adequate conservation for animal meat species identification.

\subsection{Sensitivity test}

Two approaches were attempted for sensitivity assessment in this study. Firstly, the DNA concentration was measured spectrophotometrically and then diluted in different proportions in nuclease free water and tested for PCR amplification. The limit of detection for target DNA was $1 \mathrm{pg}$ (Figure 3) and no amplification was obtained up to a dilution of $0.1 \mathrm{pg}$. It has been reported that the primers that amplify a short fragment of a target DNA give high sensitivity and the detection limit is enhanced to $1 \mathrm{pg}$ (Amaral et al., 2014; Song et al., 2017). Secondly, the meat sample was adulterated with meat mixture consisting of other species in different proportions. The meats of different animal species were mixed in various combinations and proportions for this purpose. A total of seven combinations and eight proportions were included in the study and each of the combination and proportion was tested in triplicates. All the samples yielded specific amplification product suggesting that mixing the meat from different animal species did not affect the PCR amplification. The results of detecting the animal species from adulterated meat samples were presented such as duck meat in buffalo meat (Figure 4). It was found that species-specific PCR developed was highly sensitive to identify adulteration up to the extent of $0.1 \%(\mathrm{w} / \mathrm{w})$. For all species, it was observed that the lower the percentage of the target meat in the admixture, the fainter the band obtained in the PCR with the corresponding specific primers. Similarly, a minimum detection limit of $0.1-0.01 \%(\mathrm{w} / \mathrm{w})$ for meat products was found in various literatures (Karabasanavar et al., 2013; Ali et al., 2014; Amaral et al., 2015; Kim \& Kim, 2017). Some other workers, especially by real-time PCR and other PCR methods, could even detected $<0.01 \%(w / w)$ in the adulterated meat mixtures (Kesmen et al., 2012; Cho et al., 2014; Floren et al., 2015). However, the second approach is most preferred since it is closer to the actual conditions of meat adulteration in the market.

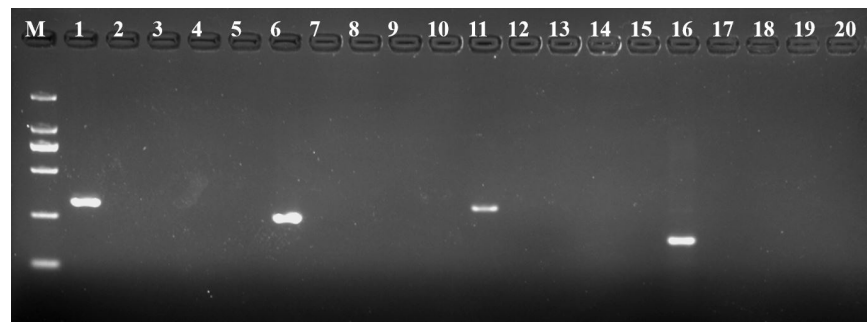

Figure 1. PCR products of raw meat samples amplified by different species-specific primers. M: DL2000 DNA marker; lanes 1-4: buffalo meat; lanes 6-9: cattle meat; lanes 11-14: pork meat; lanes 16-19: duck meat; lanes 5, 10, 15 and 20: negative control.

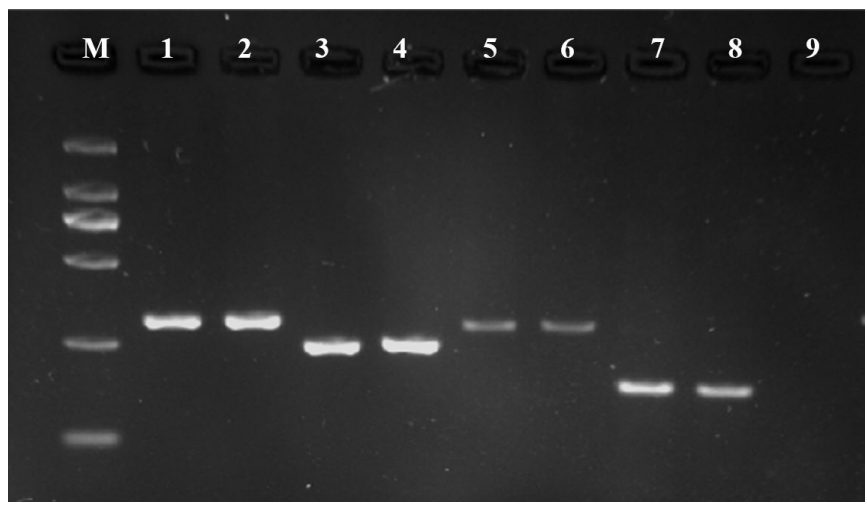

Figure 2. Specificity of multiplex PCR from raw meats. M: DL2000 DNA marker; lanes 1-2: buffalo meat; lanes 3-4: cattle meat; lanes 5-6: pork meat; lanes 7-8: duck meat; lanes 9: negative control.

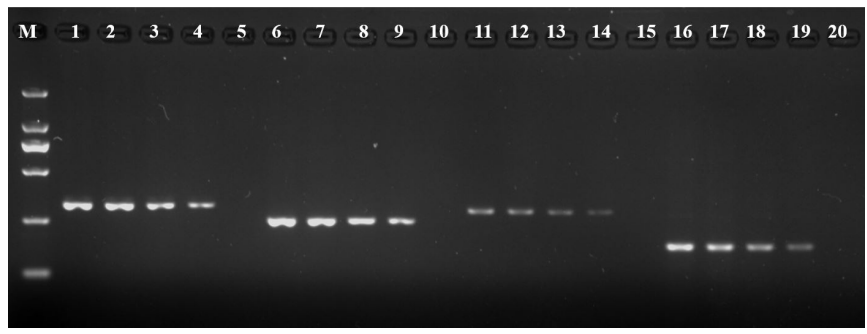

Figure 3. PCR results of serial 10-fold diluted DNA template (1000, 100, 10, 1 and 0.1 pg). M: DL2000 DNA marker; lanes 1-5: buffalo meat; lanes 6-10: cattle meat; lanes 11-15: pork meat; lanes 16-20: duck meat.

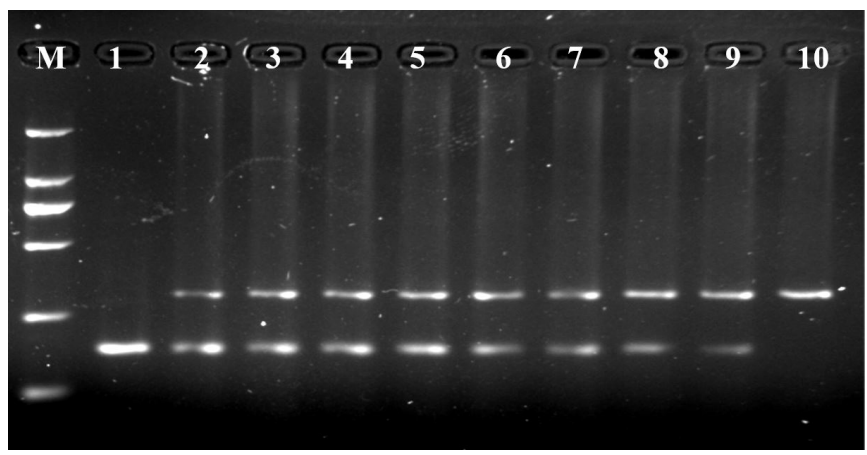

Figure 4. PCR products of binary reference mixtures of duck meat in buffalo meat. M: DL2000 DNA marker; lanes 1-10 are samples of binary mixtures containing $100 \%, 90 \%, 75 \%, 50 \%, 25 \%, 10 \%, 5 \%, 1 \%$, $0.1 \%$ and $0 \%$ of the target meats, respectively. 


\subsection{Application to commercial meat products}

The real-world use of the developed assay was demonstrated in commercial buffalo meat products. The result showed that the direct multiplex assay was efficient and could be successfully amplified (Figure 5). The adulteration was found in all meat product types including minced meat, frozen rolls, boiled meat, meat ball, vacuum-packed meat and jerky (Table 2). The highest number of adulteration (56.7\%) was found in meat ball and the lowest number (15.4\%) was found in vacuum-packed meat. The average fraud ratio was over $35 \%$ percentage (35.3\%).

The worldwide trend will be the establishment of policies of authentication of meats, especially for international trade. However, in many countries and regions, meat authentication (such as domestic animal meats, game meats, marine meats) is rare, while market mislabeling and substitution occurs frequently (Walker et al., 2013; Amaral et al., 2014; Vartak et al., 2015; Quinto et al., 2016; Galal-Khallaf et al., 2016). These occurrences negatively impact the health and safety of the consumers and the economy, as well as breach religious laws.

The adulteration of buffalo meat and meat products with other meats in many cases are unreported, especially when societal issues are not dominant such as in China. Meat vendors often use cheaper meats to adulterate buffalo meat to meet the

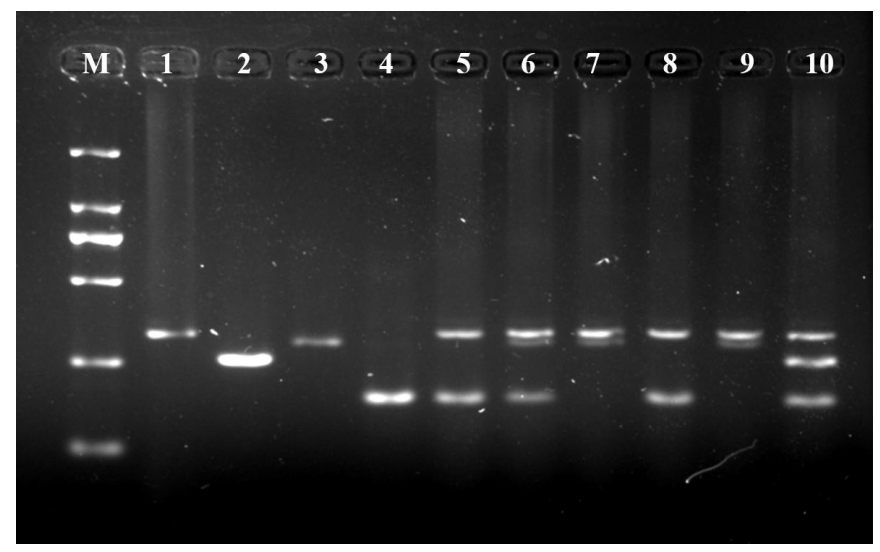

Figure 5. Detection of commercial products of buffalo meat. M: DL2000 DNA marker; lane 1: buffalo meat; lane 2: cattle meat; lane 3: pork meat; lane 4: duck meat; lane 5: frozen rolls; lane 6: minced meat; lane 7: boiled meat; lane 8: jerky; lane 9: vacuum-packed meat; lane 10: meat ball.

Table 2. Commercial samples of buffalo meat products analyzed for authentication.

\begin{tabular}{ccccc}
\hline \multirow{2}{*}{ Products } & \multicolumn{3}{c}{ Adulteration ingredients } & \multirow{2}{*}{ Fraud ratio (\%) } \\
\cline { 2 - 4 } & Cattle & Pork & Duck & \\
\hline Minced meat & + & + & + & $43.8(14 / 32)$ \\
Frozen rolls & + & + & + & $40.5(15 / 37)$ \\
Boiled meat & + & + & - & $38.2(13 / 34)$ \\
Meat ball & + & + & + & $56.7(17 / 30)$ \\
Vacuum-packed & + & + & - & $15.4(5 / 26)$ \\
meat & & & & \\
Jerky & + & + & - & $17.4(4 / 23)$ \\
\hline
\end{tabular}

Note: + stands for presence and - denotes absence. consumer demand and achieve monetary gain. In past researches, several investigators have used PCR-based approaches to identify buffalo meat from cattle meat and other animal meats targeting mitochondrial D-loop region (Karabasanavar et al., 2011; Mane et al., 2012; Girish et al., 2013), 12S rRNA gene (Patil et al., 2015), cytb gene (Gupta et al., 2011; Kumar et al., 2014; Bhat et al., 2016) and ND5 gene (Hossain et al., 2017). However, no multiplex PCR assay has been documented for the detection of commercial buffalo meat products. The development of the multiplex PCR, a technique for detecting multiple species by combining multiple primer sets into a single amplification reaction enabled the simultaneous detection of different species. It is considered that multiplex PCR is highly repeatable, time saving and affordable compared with many other PCR-based methods (Ghovvati et al., 2009). Screening of commercial food products revealed that all tested buffalo meat product types were adulterated with other animal meats (cattle meat, pork or duck) by using multiplex PCR method in this study. The average fraud ratio was over one third (35.3\%). These findings showed that this developed technology can be utilized for commercially available meat products and that it shows good sensitivity, precision and accuracy.

\section{Conclusion}

The developed multiplex PCR assay was sensitive enough to detect $1 \mathrm{pg}$ pure DNA and $0.1 \%(\mathrm{w} / \mathrm{w})$ adulterated meat under mixed matrices. Market survey revealed about $35.3 \%$ of buffalo meat products were adulterated with cattle meat, pork meat or duck meat in China.

\section{Acknowledgements}

This study was supported by the National Natural Science Foundation $(31101684,31101747)$, the six talent peaks project in Jiangsu Province (2017-NY-100) and the Natural Science Foundation (BK20141259) of Jiangsu Province in China.

\section{References}

Ali, M. E., Rahman, M. M., Hamid, S. B. A., Mustafa, S., Bhassu, S., \& Hashim, U. (2014). Canine-specific PCR assay targeting cytochrome $\mathrm{b}$ gene for the detection of dog meat adulteration in commercial frankfurters. Food Analytical Methods, 7(1), 234-241. http://dx.doi. org/10.1007/s12161-013-9672-y.

Amaral, J. S., Santos, C. G., Melo, V. S., Costa, J., Oliveira, M. B. P. P., \& Mafra, I. (2015). Identification of duck, partridge, pheasant, quail, chicken and turkey meats by species-specific PCR assays to assess the authenticity of traditional game meat Alheira sausages. Food Control, 47, 190-195. http://dx.doi.org/10.1016/j.foodcont.2014.07.009.

Amaral, J. S., Santos, C. G., Melo, V. S., Oliveira, M. B. P. P., \& Mafra, I. (2014). Authentication of a traditional game meat sausage (Alheira) by species-specific PCR assays to detect hare, rabbit, red deer, pork and cow meats. Food Research International, 60, 140-145. http:// dx.doi.org/10.1016/j.foodres.2013.11.003.

Ballin, N. Z. (2010). Authentication of meat and meat products. Meat Science, 86(3), 577-587. http://dx.doi.org/10.1016/j.meatsci.2010.06.001. PMid:20685045.

Bhat, M. M., Salahuddin, M., Mantoo, I. A., Adil, S., Jalal, H., \& Pal, M. A. (2016). Species-specific identification of adulteration in 
cooked mutton Rista (a Kashmiri Wazwan cuisine product) with beef and buffalo meat through multiplex polymerase chain reaction. Veterinary World, 9(2), 226-230. http://dx.doi.org/10.14202/ vetworld.2016.226-230. PMid:27057103.

Cho, A. R., Dong, H. J., \& Cho, S. (2014). Meat species identification using loop-mediated isothermal amplification assay targeting speciesspecific mitochondrial DNA. Han-gug Chugsan Sigpum Hag-hoeji, 34(6), 799-807. http://dx.doi.org/10.5851/kosfa.2014.34.6.799. PMid:26761677.

Dai, Z., Qiao, J., Yang, S., Hu, S., Zuo, J., Zhu, W., \& Huang, C. (2015). Species authentication of common meat based on PCR analysis of the mitochondrial COI gene. Applied Biochemistry and Biotechnology, 176(6), 1770-1780. http://dx.doi.org/10.1007/s12010-015-1715-y. PMid:26082039.

Floren, C., Wiedemann, I., Brenig, B., Schütz, E., \& Beck, J. (2015). Species identification and quantification in meat and meat products using dropletdigital PCR (ddPCR). Food Chemistry, 173, 1054-1058. http://dx.doi.org/10.1016/j.foodchem.2014.10.138. PMid:25466124.

Food and Agricultural Organization - FAO. (2017). World Livestock Database 2016. Rome. Retrieved from http://www.fao.org/home/en/

Galal-Khallaf, A., Ardura, A., Borrell, Y. J., \& Garcia-Vazquez, E. (2016). PCR-based assessment of shellfish traceability and sustainability in international Mediterranean seafood markets. Food Chemistry, 202, 302-308. http://dx.doi.org/10.1016/j.foodchem.2016.01.131. PMid:26920298.

Ghovvati, S., Nassiri, M. R., Mirhoseini, S. Z., Moussavi, A. H., \& Javadmanesh, A. (2009). Fraud identification in industrial meat products by multiplex PCR assay. Food Control, 20(8), 696-699. http://dx.doi.org/10.1016/j.foodcont.2008.09.002.

Giordano, G., Guarini, P., Ferrari, P., Biondi-Zoccai, G., Schiavone, B., \& Giordano, A. (2010). Beneficial impact on cardiovascular risk profile of water buffalo meat consumption. European Journal of Clinical Nutrition, 64(9), 1000-1006. http://dx.doi.org/10.1038/ ejcn.2010.108. PMid:20588291.

Girish, P. S., Haunshi, S., Vaithiyanathan, S., Rajitha, R., \& Ramakrishna, C. (2013). A rapid method for authentication of Buffalo (Bubalus bubalis) meat by Alkaline Lysis method of DNA extraction and species specific polymerase chain reaction. Journal of Food Science and Technology, 50(1), 141-146. http://dx.doi.org/10.1007/s13197011-0230-6. PMid:24425899.

Gupta, R., Rank, D. N., \& Joshi, C. G. (2011). Duplex-PCR for identification and differentiation of cattle and buffalo processed meat. Buffalo Bulletin, 31(1), 6-11.

Hargin, K. D. (1996). Authenticity issues in meat and meat products. Meat Science, 43(Suppl. 1), 277-289. http://dx.doi.org/10.1016/03091740(96)00072-1. PMid:22060658.

Hossain, M. A. M., Ali, M. E., Hamid, S. B. A., Asing, Mustafa, S., Desa, M. N. M., \& Zaidul, I. S. M. (2017). Targeting double genes in multiplex PCR for discriminating bovine, buffalo and porcine materials in food chain. Food Control, 73, 175-184. http://dx.doi. org/10.1016/j.foodcont.2016.08.008.

Karabasanavar, N. N. S., Singh, S. P., Umapathi, V., Girish, P. S., Shebannavar, S. N., \& Kumar, D. (2011). Authentication of carabeef (water buffalo, Bubalus bubalis) using highly specific polymerase chain reaction. European Food Research and Technology, 233(6), 985-989. http://dx.doi.org/10.1007/s00217-011-1583-9.

Karabasanavar, N. S., Singh, S. P., Kumar, D., \& Shebannavar, S. N. (2013). Development and application of highly specific PCR for detection of chicken (Gallus gallus) meat adulteration. European Food Research and Technology, 236(1), 129-134. http://dx.doi. org/10.1007/s00217-012-1868-7.
Kesmen, Z., Yetiman, A. E., Sahin, F., \& Yetim, H. (2012). Detection of chicken and turkey meat in meat mixtures by using real-time PCRassays. Journal of Food Science, 77(2), C167-C173. http://dx.doi. org/10.1111/j.1750-3841.2011.02536.x. PMid:22309374.

Kim, M. J., \& Kim, H. Y. (2017). Species identification of commercial jerky products in food and feed using direct pentaplex PCR assay. Food Control, 78, 1-6. http://dx.doi.org/10.1016/j.foodcont.2017.02.027.

Kumar, A., Kumar, R. R., Sharma, B. D., Gokulakrishnan, P., Mendiratta, S. K., \& Sharma, D. (2015). Identification of species origin of meat and meat products on the DNA basis: a review. Critical Reviews in Food Science and Nutrition, 55(10), 1340-1351. http://dx.doi.org/1 0.1080/10408398.2012.693978. PMid:24915324.

Kumar, D., Singh, S. P., Karabasanavar, N. S., Singh, R., \& Umapathi, V. (2014). Authentication of beef, carabeef, chevon, mutton and pork by a PCR-RFLP assay of mitochondrial cytb gene. Journal of Food Science and Technology, 51(11), 3458-3463. http://dx.doi. org/10.1007/s13197-012-0864-z. PMid:26396346.

Mane, B. G., Mendiratta, S. K., \& Tiwari, A. K. (2012). Beef specific polymerase chain reaction assay for authentication of meat and meat products. Food Control, 28(2), 246-249. http://dx.doi.org/10.1016/j. foodcont.2012.05.031.

Murthy, T. R. K., \& Devadason, I. P. (2003). Buffalo meat and meat products: an overview. In Proceedings of the 4th Asian Buffalo Congress on Buffalo for Food, Security and Employment (pp. 193-199). New Delhi: Asian Buffalo Association.

Nakyinsige, K., Man, Y. B., \& Sazili, A. Q. (2012). Halal authenticity issues in meat and meat products. Meat Science, 91(3), 207-214. http://dx.doi.org/10.1016/j.meatsci.2012.02.015. PMid:22405913.

Patil, M., Deepika, S., \& Bannalikar, A. S. (2015). Mt 12S rRNA gene PCR-RFLP based assay for meat authentication. The Indian Journal of Veterinary Sciences and Biotechnology, 10, 66-70.

Quinto, C. A., Tinoco, R., \& Hellberg, R. S. (2016). DNA barcoding reveals mislabeling of game meat species on the U.S. commercial market. Food Control, 63(1), 268. http://dx.doi.org/10.1016/j. foodcont.2015.12.005.

Sentandreu, M. Á., \& Sentandreu, E. (2014). Authenticity of meat products: tools against fraud. Food Research International, 60, 19-29. http://dx.doi.org/10.1016/j.foodres.2014.03.030.

Song, K. Y., Hwang, H. J., \& Kim, J. H. (2017). Ultra-fast DNA-based multiplex convection PCR method for meat species identification with possible on-site applications. Food Chemistry, 229, 341-346. http://dx.doi.org/10.1016/j.foodchem.2017.02.085. PMid:28372182.

Spink, J., \& Moyer, D. C. (2011). Defining the public health threat of food fraud. Journal of Food Science, 76(9), R157-R163. http://dx.doi. org/10.1111/j.1750-3841.2011.02417.x. PMid:22416717.

Spychaj, A., Szalata, M., Słomski, R., \& Pospiech, E. (2016). Identification of bovine, pig and duck meat species in mixtures and in meat products on the basis of the mtDNA cytochrome oxidase subunit I (COI) gene sequence. Polish Journal of Food and Nutrition Sciences, 66(1), 31-36. http://dx.doi.org/10.1515/pjfns-2015-0051.

Vartak, V. R., Narasimmalu, R., Annam, P. K., Singh, D. P., \& Lakra, W. S. (2015). DNA barcoding detected improper labelling and supersession of crab food served by restaurants in India. Journal of the Science of Food and Agriculture, 95(2), 359-366. http://dx.doi. org/10.1002/jsfa.6728. PMid:24796530.

Walker, M. J., Burns, M., \& Burns, D. T. (2013). Horse meat in beef products-species substitution 2013. Journal of the Association of Public Analysts, 41, 67-106. 